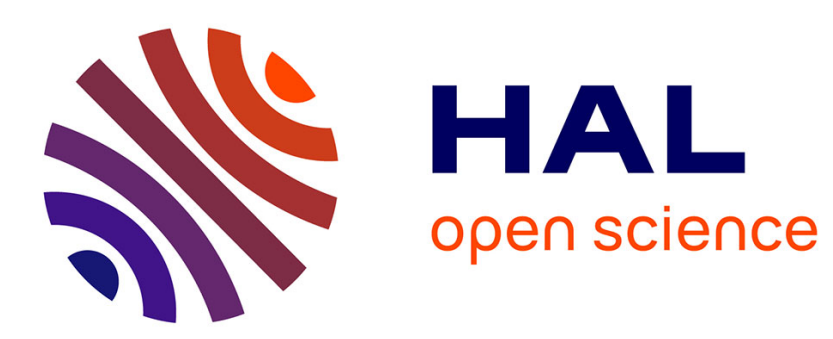

\title{
Does the Bush Administrationś climate policy mean climate protection?
}

Odile Blanchard, James F. Perkaus

\section{To cite this version:}

Odile Blanchard, James F. Perkaus. Does the Bush Administrationś climate policy mean climate protection?. Energy Policy, 2004, 32 (18), p. 1993-98. halshs-00001683

\section{HAL Id: halshs-00001683 \\ https://shs.hal.science/halshs-00001683}

Submitted on 11 Jun 2004

HAL is a multi-disciplinary open access archive for the deposit and dissemination of scientific research documents, whether they are published or not. The documents may come from teaching and research institutions in France or abroad, or from public or private research centers.
L'archive ouverte pluridisciplinaire HAL, est destinée au dépôt et à la diffusion de documents scientifiques de niveau recherche, publiés ou non, émanant des établissements d'enseignement et de recherche français ou étrangers, des laboratoires publics ou privés. 


\title{
Does the Bush Administration's climate policy mean climate protection? \\ Odile Blanchard $^{1}$, James F. Perkaus ${ }^{2}$
}

\author{
Submitted to Energy Policy for publication as a Viewpoint, May 3, 2004
}

\begin{abstract}
"That's a big 'no," declared then-White House spokesman Ari Fleischer at a 2001 briefing responding to a question about whether President George W. Bush would ask Americans to refrain from consuming so much energy. "The President," he continued, "believes that it's an American way of life, that it should be the goal of policy-makers to protect the American way of life. The American way of life is a blessed one (...) The President considers Americans' heavy use of energy a reflection of the strength of our economy, of the way of life that the American people have come to enjoy.",
\end{abstract}

This political will of unrestricting the U.S. citizens' energy consumption explains some current energy features of the U.S. economy. On a yearly basis, the U.S. citizen uses 8 tons of oil equivalent (toe) of primary energy whereas the OECD and world averages respectively stand at 4.7 and 1.6 toe per capita. The U.S. economy relies on fossil fuels for 85 percent of its energy supply and emits 21 percent of the world greenhouse gases with five percent of the world population. If the share of fossil fuels in the energy balance and the efficiency level of energy technologies remain fairly constant, an increasing use of energy will lead to still higher levels of greenhouse gas emissions.

What are the prospects for participation in climate protection by the United States against this backdrop? Our paper addresses this question by analyzing the two major components of the Bush Administration's climate policy, namely an emission intensity target and a technology strategy. The question is whether those components will generate emission reductions that will contribute to the stabilization of the greenhouse gas concentration at a safe level in the long run.

The first section sketches the history of the Bush Administration's climate policy. The second section shows that the emission intensity target does not lead to emission reductions. The third section underscores the uncertain emission reduction outcomes of the bet placed on low carbon emitting technologies. The fourth and last section examines current climate protection actions in the United States, other than those of the Bush Administration.

\section{The main principles of the Bush Administration's climate policy ${ }^{4}$}

Shortly after taking office in early 2001 President George W. Bush repudiated the Kyoto Protocol because the treaty "exempts 80 percent of the world, (...), from compliance", and it "would cause serious harm to the U.S. economy", especially given the current scientific and technical uncertainties (Bush, 2001).

\footnotetext{
${ }^{1}$ Associate Professor, Department of Energy and Environmental Policy, LEPII, University of Grenoble, France.

${ }^{2}$ President, Perkaus \& Associates, a Chicago-based consultancy, United States of America.

${ }^{3}$ Transcript: White House Daily Briefing, 7 May 2001. Online at: http://www.usembassyisrael.org.il/publish/peace/archives/2001/may/0507c.html

${ }^{4}$ For a detailed timeline of the Bush Administration's climate policy, see: Blanchard, O. 2003. The Bush Administration Climate Proposal : Rhetoric and Reality, online at :

http://www.ifri.org/files/OB Bush Climate Policy.pdf
} 
President Bush announced his Administration's alternative solution to address climate change in February 2002, as part of the "Clear Skies and Global Climate Change Initiatives" (Bush, 2002; White House, 2002). The proposal called for an 18 percent reduction in the greenhouse gas intensity over the next ten years. Unlike a fixed target that caps absolute emissions, this intensity target limits greenhouse gas emissions as a ratio of the gross domestic product (GDP). Voluntarism was proposed as the way to achieve the target. A review of the efforts by 2012 was called for, to examine whether the target has been met. If not, additional measures including market-based programs were suggested.

The need for more research was emphasized, to reduce scientific uncertainties related to global warming magnitude and impacts, and to develop climate-friendly technologies that will be cost effective. Budget credits were announced for climate science research and climate technology initiatives.

In the international field, President Bush reaffirmed the U.S. commitment to the UNFCCC, and the non-interference of the United States towards other states that may choose to ratify the Kyoto Protocol. He praised the greenhouse gas intensity approach for developing countries. ${ }^{5}$

Since February 2002, the Administration has followed the voluntary, flexible, science-based course of action set out in the "Global Climate Change Initiative". The Environmental Protection Agency (EPA) and the Department of Energy have launched separate initiatives towards voluntary corporate commitments to reduce greenhouse gas emissions. In the research field, the Strategic Plan for the Climate Change Science Program released in July 2003 presents the research strategy of the Bush Administration to reduce the scientific uncertainties surrounding climate change. Various innovative technological projects have been launched.

All these elements point to key principles that shape the U.S. climate policy. Primacy is given to factors perceived to promote economic growth. Only voluntary (not mandatory) commitments are called for. Allowing for time and gradualism is deemed essential both to improve climate change science knowledge and to implement technologies that will be more cost effective. Do these near term and longer term principles lead to meaningful climate protection? The next two sections address the question, first in a short run perspective, then in the long run.

\section{The emission intensity target: the emission reduction missing link in the short run}

According to the Administration, the Kyoto Protocol "would have cost [the] economy up to $\$ 400$ billion and [lead to the loss of] 4.9 million jobs" (Bush, 2002). Instead, the Bush Administration has repeatedly made the case for a climate policy that should not harm the U.S. economy, namely that should not jeopardize economic growth and jobs. The reduction of the greenhouse gas intensity announced in February 2002 is the Administration's way to address this concern for economic growth.

Emission targets typically fall under one of two types, fixed and dynamic. A Kyoto-type fixed target limits allowable emission levels, regardless of economic growth. The benefits of

\footnotetext{
${ }^{5}$ This position is a major flip of the Bush Administration relative to its previous year's stance on developing countries to take on emission limitation commitments.
} 
knowing with certainty the quantity capped comes at a price. Fixed targets are more stringent and costly in absolute terms when GDP growth is high, compared to a low-economic growth scenario. This is particularly true when the greenhouse gas emissions are closely correlated to the GDP. Unlike fixed targets, allowable emission levels of a dynamic target fluctuate according to a specified variable (or set of variables), such as U.S. GDP under the Bush Administration emission intensity target. A dynamic target therefore reduces the cost of economic uncertainty but at the price of environmental certainty.

Furthermore, the target adopted by the Bush Administration is quantitatively far more lenient than the Kyoto Protocol's target. Whereas the Kyoto Protocol would have required a sevenpercent emissions reduction by 2008-2012 relative to 1990 baseline, the Global Climate Change Initiative proposed target will most likely allow emissions to grow appreciably from 2002 to 2012. As President Bush puts it, the reduction target in the greenhouse gas emission intensity constitutes a "path to slow the growth of greenhouse gas emissions and, as science justifies, to stop and then reverse the growth of [U.S.] emissions" (Bush, 2002).

Nevertheless, the Administration's goal to cut the U.S. greenhouse gas intensity by 18 percent over the next ten years is similar to the trend observed in the 1990s when no climate mitigation actions, other than largely ineffective voluntary programs, were implemented. After declining by 22 percent in the 1980s, the U.S. greenhouse gas emission intensity decreased by 17 percent over the last decade, mainly as a result of combined effects of energy efficiency improvements and structural changes of the economy, such as transitioning from energy-intensive industries towards information and service activities. The Bush Administration's goal largely continues the past trend. It is only slightly below the businessas-usual ("reference") projection built up by the Energy Information Administration (EIA) for 2002-2012 (Figure 1).

\section{Figure 1: The Greenhouse Gas Intensity Target: a 1990s’ déjà vu}

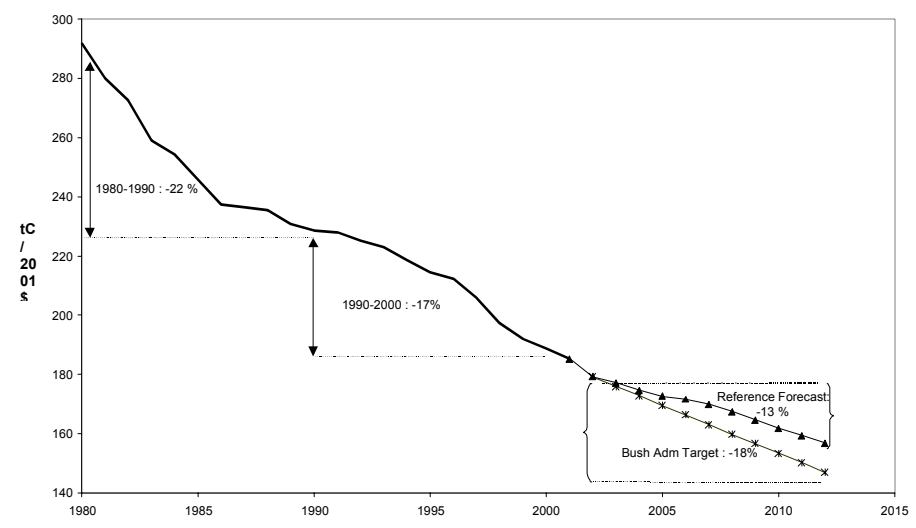

\section{Sources and notes:}

Historical emissions (1980-2000): EIA, Annual Energy Review 2001; 2001 emissions: EPA, 2003 National Inventory Tables;

GHG emissions projections ("Reference Forecast") are drawn from $\mathrm{CO}_{2}$ projections of EIA's 2003 Annual Energy Outlook and based on the assumption that the emissions of the other GHGs have the same growth rate as $\mathrm{CO}_{2}$.

Historical GDP data: Bureau of Economic Analysis; GDP projections (Reference Forecast): EIA's 2003 Annual Energy Outlook 
In addition, decreased emission intensity would translate into a substantial growth of U.S. greenhouse gas emissions over the coming decade, at a pace comparable to that of the last decade. As the greenhouse gas intensity is a ratio, it may decrease even though both its numerator and denominator increase: this is particularly the case when the numerator increases at a slower rate than the denominator. The Administration expects the denominator of the greenhouse gas intensity ratio (i.e., U.S. GDP) to increase by almost 39 percent between 2002 and 2012 on a business-as-usual trend. ${ }^{6}$ Reaching the target of an 18 percent decrease of the greenhouse gas intensity over the same period entails that the numerator of the ratio (i.e., greenhouse gas emissions) is allowed to grow by 14 percent. $^{7}$ Greenhouse gas emission reductions are unlikely in the near future. The emission intensity target set by the Bush Administration does not address global climate protection in the short term.

In fact, a 14 percent growth rate of greenhouse gas emissions is the emission increase that occurred over the last decade. It stands seven percentage points below the 2002-2012 projected 21 percent increase of the business-as-usual ("reference") emissions (figure 2). This could hardly be called an "ambitious" initiative to slow global climate change.

\section{Figure 2: Greenhouse gas emissions: up and up}

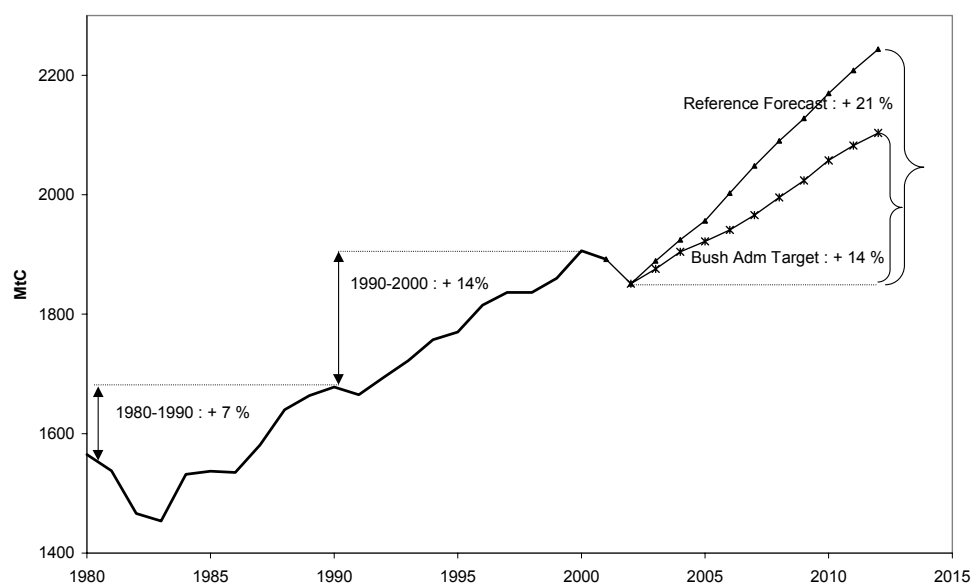

Sources and notes:

Historical emissions (1980-2000): Energy Information Agency (EIA), Annual Energy Review 2001; 2001 emissions: Environmental Protection Agency (EPA), 2003 National Inventory Tables;

GHG emissions projections ("Reference Forecast") are drawn from $\mathrm{CO}_{2}$ projections of EIA's 2003 Annual Energy Outlook and based on the assumption that the emissions of the other GHGs have the same growth rate as $\mathrm{CO}_{2}$.

Still virtually all climate experts agree that climate change is a long-term issue: the causal chain from societal activities that emit greenhouse gases, through atmosphere concentration build up, temperature increase, climate change and finally to climate impacts spans many decades. There is also general agreement, including in the Bush Administration, that stabilizing greenhouse gas concentrations at a safe level in the long term is the necessary goal to protect the climate.

\footnotetext{
${ }^{6}$ This growth rate is that of the "Reference case" of the Annual Energy Outlook. Source: http://www.eia.doe.gov/oif/aeo/

${ }^{7}$ The inferred allowance lies in the context of the Global Climate Change Initiative voluntary (not mandatory) limit.
} 
Various emission paths can lead to the same atmospheric concentration level. They all imply emissions reductions at some point. For example, in its Third Assessment Report, the Intergovernmental Panel on Climate Change (IPCC) has reviewed the emission trajectories of various emission mitigation scenarios that reach a $\mathrm{CO}_{2}$ concentration stabilization between 450 and 550 parts per million volume (ppmv) (IPCC, 2001). Although the emission trajectories generally show an inverted $U$ shape, the range of the maximum emission level, as well as the time spans over the $21^{\text {st }}$ century for the three stages -emission growthstabilization - decrease- are very diverse. Therefore, the sharp emission increase expected in the United States over the current decade does not a priori preclude the international community from reaching, for example, the $550 \mathrm{ppmv} \mathrm{CO}_{2}$ concentration stabilization level officially set by the European Union for 2100.

Advocates of delaying emission reductions, including the Bush Administration, point to the timing imbalance between short-term economic costs of emission reductions and long-term environmental benefits, should emissions be cut in the short term (CEA, 2002, chapter 6). They particularly point to premature capital retirement causing high economic costs. However, reducing emissions sooner rather than later allows to benefit from opportunities of relatively low-cost measures that would be otherwise forgone, and opens up the spectrum of future emission pathways towards a safer concentration stabilization level. Postponing emission reductions may entail that some long-lasting carbon-intensive investments might be implemented in the near term, whereas they would not be economically efficient if emissions were to be immediately reduced.

Postponing emission reductions inevitably implies that emissions need to be reduced more dramatically in the future to meet the same long term goal. As the United States is not positioning itself for emission reductions in the short term, it will need payoffs in the longer run. Will technological innovations generate substantial emission reductions over the next decades?

\section{An uncertain bet on technological innovations in the long run}

The United States has favored research and technology innovation for decades. On balance, this strategy has paid handsome dividends. The Bush Administration confidence that technology can tackle any problem is reflected in the climate field by its stance on climatefriendly "breakthrough" technologies to reduce greenhouse gas emissions in the long run.

The federal funds devoted to technology developments in energy efficiency and renewable energy have not gained substantial momentum over the years of the Bush Administration. Conversely, the budget requests got a strong boost in the Administration's newly-defined priorities aimed to develop low carbon technologies, namely, the hydrogen fuel and carbon sequestration research programs.

The National Hydrogen Energy Map released in November 2002 defines directions and priorities in the hydrogen R\&D programs. A $\$ 1.7$ billion- Hydrogen Fuel Initiative will focus on hydrogen-powered fuel cells for use in vehicles and electricity generation over the next five years. Through the FreedomCAR public-private partnership in particular, U.S. research strategy for future road vehicles brings to a halt the Partnership for a New Generation of Vehicles, the Clinton-era program to develop highly energy efficient vehicles. 
Simultaneously, a ten-year $\$ 1$ billion public-private project has been launched for electricity generation from hydrogen-powered turbines and carbon sequestration. Under the FutureGen initiative, a prototype plant will turn coal into a hydrogen-rich gas and will capture the carbon dioxide in a form that can be sequestered. The FutureGen initiative illustrates the strong link between carbon sequestration R\&D and hydrogen research programs in the United States. Given ample reserves, coal is the most promising fuel source in the United States for hydrogen production. In this context, hydrogen-generated electricity will be carbon-free only if carbon emissions from hydrogen production are sequestered.

Increased research emphasis is given to carbon capture and sequestration, which "offers the potential for countries to achieve large-scale reductions of greenhouse gases without necessitating massive and economically disruptive changes to their energy infrastructures". A Carbon Sequestration Technology Roadmap and Program Plan was issued in January 2003. A Carbon Sequestration Leadership Forum was created in February 2003 to bring international experts to discuss the latest research and technologies developed in the field. Innovative technological projects have been launched by the Department of Energy in March 2004 , costing over $\$ 4$ billion over three years.

While the Bush Administration points to the need to reduce future net greenhouse gas emissions, its climate policy places a big bet on future technological developments to achieve those reductions. The bet is that the new technologies will cost-effectively compensate for the current and near term emission increases, simultaneously allowing for the protection of the energy-intensive American consumption habits. But those technologies are largely in early stages of development. On the one hand, they evict other potential efficient technologies, such as the already mentioned Partnership for a New Generation of Vehicles. On the other hand, their outcomes are uncertain in terms of emission reduction potential, cost, and timing. The policy question is about whether cost-effective, climate-friendly technological breakthroughs will emerge before the emission pathways lock the world into unsafe greenhouse gas concentrations. Breakthrough technologies may take decades to be deployed and penetrate the market. It is too early to assess whether and when the new technologies will significantly reduce U.S. emissions.

Moreover the current boost of hydrogen- and carbon sequestration- technologies requires sustained financial support over a long period of time before it may deliver outcomes. Depending on the priorities of each Presidential Administration, this support may be challenged by changes in the White House residents over the next decades. Considering all these uncertainties, there is no guarantee that the Bush Administration's long term policy focus will deliver climate protection.

Sections 2 and 3 have respectively shown that the Bush Administration climate policy will most likely not generate greenhouse gas emission reductions in the short run and does not assure any net reductions even in the longer term. What are the prospects then for participation of the United States in the much needed international effort to protect the climate? The next section addresses this question.

\section{4. Bottom-up prospects for climate protection in the United States}

\footnotetext{
${ }^{8}$ U.S. Department of Energy, Office of Fossil Energy, February 2003
} 
The options adopted by the Bush Administration in the climate field reflect the weight of some interest groups in policy-making. Specifically, the energy and extractive-related industries have been the most powerful to influence the design of the Bush Administration's energy policy and, in the background, climate policy. ${ }^{9}$ The energy lobby can take well-earned credit for the emission intensity target, the voluntary (instead of mandatory) measures, as well as the technological options adopted by the Bush Administration to address the climate issue. Against this backdrop, it seems clear that meaningful mitigation measures will not be forthcoming from the current Presidential Administration-at least, not without a prod.

To this end, a few encouraging signs are on the horizon. Congressional activity around climate change issues has considerably increased over the last Congress sessions. ${ }^{10} \mathrm{~A}$ bipartisan greenhouse gas cap-and-trade bill (the Climate Stewardship Act S.139) was introduced in January 2003 in the Senate. A revised version came within seven votes of passing the Senate in October. Its companion House bill (the Climate Stewardship Act H.R. 4067) was introduced in the House of Representatives in March 2004. These bills and others reflect the growing domestic concern to address climate change more aggressively than through the approach adopted by the Bush Administration.

Numerous emission limitation actions are carried out at the subnational level - individual states and municipalities, corporations, civil society. Many states have enacted legislation to reduce their greenhouse gas emissions. For instance, New Jersey has set a greenhouse gas emission reduction target of 3.5 percent below 1990 level by 2005 ; Massachusetts has imposed a ten percent $\mathrm{CO}_{2}$ emission reduction relative to 1997-1999 levels by 2006 or 2008 to old power plants ; the standard for $\mathrm{CO}_{2}$ emissions from new power plants in Oregon has been set 17 percent below the most efficient natural gas-fired plant in operation in the United States ; fifteen states have imposed their Renewable Portfolio Standard to boost the electricity produced from renewable resources ; California has passed a law to set by 2005 maximum but economically feasible emission standards for new passenger vehicles sold in the state, to be applied to model years 2009 and beyond. Corporations are increasingly taking steps to limit their greenhouse gas emissions. ${ }^{11}$ Universities, religious groups, and non governmental organizations are also undertaking efforts to fight against climate change. ${ }^{12}$

All these actions at the subnational level are not sufficient to curb the U.S. greenhouse gas emission increase. But they inform and educate; they legitimize climate change as an important social issue. It is these activities that may build critical mass that leads to a more stringent federal climate policy in the near future.

\section{Conclusion}

\footnotetext{
${ }^{9}$ Reports from various environmental non-governmental organizations (NGOs) point to the strong link between the energy industry and the White House energy task force. See for example World Watch, vol 14, \# 4, July/August 2001; see also : NRDC "Heavily Censored Energy Department Papers Show Industry is the Real Author of Administration's Energy Task Force Report", available at : http://www.nrdc.org/media/pressreleases/020327.asp

${ }^{10}$ The number of climate change-related bills, resolutions, and amendments introduced into Congress increased from seven in the $105^{\text {th }}$ Congress, to twenty-five in the $106^{\text {th }}$ Congress, eighty-five in the $107^{\text {th }}$ Congress and nearly 70 in the first year of the $108^{\text {th }}$ Congress (2003-2004). See (Pew Center, 2004).

${ }^{11}$ See (Pew Center, 2004).

${ }^{12}$ See for example (Grist Magazine, 2002)
} 
The Bush Administration climate policy assigns heaviest weighting to avoiding near-term economic costs linked to immediate emissions reductions, whereas the long-term risk of climate disruption is met by the confidence in future technological breakthroughs. Along this line, the emission intensity target set by the Administration will most likely allow near term emissions to grow, betting on a drastic decrease of net emissions from innovative technological carbon paths in the long run. Therefore the Bush Administration climate policy does not guarantee any meaningful contribution to climate protection. So as not to be misunderstood, we applaud research and development investment in breakthrough technologies; yet, coupled with the lenient greenhouse gas intensity target, it is simply inadequate.

The United States is the largest greenhouse gas emitter in the world. It is among the richest countries, per capita. Proportionate responsibility for accumulated atmospheric emissions and capacity to respond are thus both present, and call for meaningful climate mitigation action now. The way forward will most likely not come from the policies of the current Administration, but rather from the growing concern about the climate issue in Congress and elsewhere. The efforts to fight against climate change at the state, corporate and civil society levels will outlive the current Administration. These combined forces may well raise the playing field at the federal level in the near future, whatever the outcome of the forthcoming presidential elections.

\section{Acknowledgements}

The authors are grateful to Kevin Baumert, Senior Associate at the World Resources Institute, Washington, D.C., for his helpful comments on an earlier version. The authors also wish to thank Dominique Finon, Senior Research Fellow at Centre International de Recherche sur l'Environnement et le Développement (EHESS \& CNRS, Paris) for his fruitful review of the final draft. The authors are solely responsible for the contents of the article.

\section{Bibliography}

Bush, G.W. 2001. Letter from the President to Senators Hagel, Helms, Craig and Roberts. March 13. Online at:

http://www.whitehouse.gov/news/releases/2001/03/20010314.html

Bush, G.W. 2002. President Announces Clear Skies and Global Climate Change Initiative. Feb 14. Online at:

http://www.whitehouse.gov/news/releases/2002/02/20020214-5.html.

CEA (Council of Economic Advisers). 2002. The Annual Report of the Council of Economic Advisers. Washington D.C.

Grist Magazine. 2002. Power Shift : Looking for Leadership on Climate Change. July 31.

IPCC (Intergovernmental Panel on Climate Change). 2001. Climate Change 2001: Mitigation, Contribution of Working Group III to the Third Assessment Report of the Intergovernmental Panel on Climate Change. Cambridge: Cambridge University Press. 
Pew Center. 2004. Climate Change Activities in the United States, 2004 Update. Online at : http://www.pewclimate.org/docUploads/74241\%5FUS\%20Activities\%20Report $\% 5$ F040604 $\% 5 \mathrm{~F} 075445 \% 2 \mathrm{Epdf}$

White House. 2002. Global Climate Change Policy Book. Online at: http://www.whitehouse.gov/news/releases/2002/02/climatechange.html 